\title{
A taxonomic review of the genus Phaeocystis
}

\author{
Linda Medlin • Adriana Zingone
}

Received: 20 October 2005 / Accepted: 22 August 2006 / Published online: 15 March 2007

(C) Springer Science+Business Media B.V. 2007

\begin{abstract}
Phaeocystis is recognized both as a nuisance and as an ecologically important phytoplankton species. Its polymorphic life cycle with both colonial and flagellated cells causes many taxonomic problems. Sequence variation among 22 isolates representing a global distribution of the genus has been compared using three molecular markers. The ribulose-1,5-bisphosphate carboxylase/oxygenase (RUBISCO) spacer is too conserved to resolve species. The most conserved $18 \mathrm{~S}$ ribosomal deoxyribonucleic acid (rDNA) analysis suggests that an undescribed unicellular Phaeocystis sp. (isolate PLY559) is a sister taxon to the Mediterranean unicellular Phaeocystis jahnii; this clade branched prior to the divergence of all other Phaeocystis species, including the colonial ones. The internal transcribed spacer (ITS) region shows sufficient variation that some spatial population structure can be recovered, at least in $P$. antarctica. $P$. globosa and $P$. pouchetii have
\end{abstract}

L. Medlin ( $\square)$

Alfred Wegener Institute for Polar and Marine

Research, Am Handelshafen 12, Bremerhaven, 27570,

Germany

e-mail:1kmedlin@awi-bremerhaven.de

A. Zingone

Stazione Zoologica Anton Dohrn, Villa Comunale, 80121 Naples, Italy multiple different ITS copies, suggestive of cryptic species that are still able to hybridize. A molecular clock has been constructed that estimates the divergence of the cold water colonial forms from the warm-water colonial forms to be about $30 \mathrm{Ma}$ and the divergence of $P$. antarctica and $P$. pouchetii to be about $15 \mathrm{Ma}$. A short description of the colonial stage and the flagellated stage for each formally recognized species is provided. Morphological information is also provided on a number of undescribed species. These include the strain Ply 559, consisting of non-colonial cells with peculiar tubular extrusomes, a second non-colonial species from the north western Mediterranean Sea producing a lot of mucus, and a colonial species with scale-less flagellates found in Italian waters. In addition, three flagellated morphotypes with scales different from those of $P$. antarctica were reported in the literature from Antarctic waters. The picture emerging from both molecular and morphological data is that the number of species in the genus is still underestimated and that cryptic or pseudocryptic diversity requires a sound assessment in future research of this genus. Based on all published observations, an emended description of the genus is provided.

Keywords Molecular clock $\cdot$ Phaeocystis antarctica $\cdot P$. cordata $\cdot P$. globosa $\cdot$

P. jahnii $\cdot$ P. pouchetii $\cdot$ P. scrobiculata . rDNA analysis 


\section{Introduction}

Phaeocystis Lagerheim is a cosmopolitan bloomforming alga that is often recognized both as a nuisance alga and an ecologically important member of the phytoplankton (Davidson 1985; Lancelot et al. 1987; Smith et al. 1991; Davidson and Marchant 1992; Baumann et al. 1994; Schoemann et al. 2005; Veldhuis and Wassmann 2005). Its various life forms can make large-scale blooms that are often avoided by fish (Chang 1983) and appear detrimental to the growth and reproduction of shellfish and macrozooplankton (Davidson and Marchant 1992) or are ichthyotoxic (Shen et al. 2004). Massive areas of pollution are created when dissolved organic compounds released by Phaeocystis during declining bloom conditions accumulate, foam and then wash onshore (Lancelot et al. 1987). Phaeocystis is a major contributor to the global sulphur budget by releasing substantial quantities of dimethylsulfide propionate (DMSP) (Keller et al. 1989; Baumann et al. 1993), which is metabolized to dimethylsulfide (DMS) as the cells are grazed or infected and lysed by viruses. It may play yet another important ecological role with its production of ultraviolet B (UV-B)-absorbing compounds (Marchant et al. 1991; Davidson and Marchant 1992).

Phaeocystis has a polymorphic life cycle with both colonial and flagellated cells (Kornmann 1955; Whipple et al. 2005). The colonial stage, with cells very loosely interconnected and enclosed in a thin skin (Hamm et al. 1999), is most easily recognized, although some species may form mucilaginous colonies or do not seem to have a colonial stage. Thousands of cells can occur in a colony that may reach $2 \mathrm{~cm}$ in diameter (Jahnke and Baumann 1987; Verity et al. 1988; Rousseau et al. 1994; Davidson and Marchant 1992). Colony sizes of $3 \mathrm{~cm}$ or more have been reported in blooms from China (Shen et al. 2004). The difficulty in assigning a specific name to the colonial stage has caused much taxonomic confusion. Flagellated cells have two parietal chloroplasts and two flagella, which may be equal or unequal in length and heterodynamic. A short haptonema is present between the two flagella, which may or may not have a swollen end. The flagellated cells may be naked or have two layers of different shaped organic scales. Some flagellated cells also produce groups of filaments, which are extruded from the cell and assume a characteristic pattern.

The genus was erected by Lagerheim in 1893 to accommodate the colonial stage of an alga described originally as Tetraspora poucheti by Hariot in Pouchet (1892). Phaeocystis pouchetii (its correct orthography) occurs in cold waters and in its globular, lobed colonies, cells are arranged in packets of four (see Jahnke and Baumann 1987 for illustrations). Phaeocystis globosa was described by Scherffel (1900) from temperate waters and forms spherical colonies with cells arranged homogeneously within the colony (Jahnke and Baumann 1987), whereas older stages can assume distorted pear shapes (Bätje and Michaelis 1986). Early workers separated $P$. pouchetii and $P$. globosa based on different distributions and colonial morphologies until Kornmann (1955) doubted the differentiation between the two species. From his life-cycle studies, he considered that $P$. globosa cell types appeared to be juvenile forms of $P$. pouchetii. Since that report, colony morphology has been judged an unreliable specific character.

Sournia (1988) reviewed the diagnostic features of Phaeocystis, and discussed the reliability of the nine valid species published since the last century. He discarded two species from the genus, $P$. fuscescens (Braun) De Toni and P. giraudyi (Derbès and Solier) Hamel, because they did not fit the genus and probably not even the class characteristics. The descriptions of four species, two from cold waters, $P$. antarctica Karsten and $P$. brucei Mangin, and two from temperate waters, $P$. amoeboidea Büttner and P. sphaeroidea Büttner, were all judged as very superficial. The poor illustrations and unlikely features, including one chloroplast per cell and no haptonema (Büttner 1911), were probably the reasons why the two temperate species have never been mentioned again in the literature. For similar reasons the two Antarctic species were reported rarely and not studied again. As for the two most frequently recorded species, $P$. pouchetii (Hariot in Pouchet) Lagerheim and $P$. globosa Scherffel, they had been studied in more detail yet no element was available to keep them separate. Therefore Sournia 
suggested that the name $P$. pouchetii or, better, $P$. cf. pouchetii should have been used for the colonial Phaeocystis species pending new information. The only other reliable species was Phaeocystis scrobiculata Moestrup, described with modern methods but known only from the flagellated state (Moestrup 1979). Without convincing information on the differentiation between $P$. pouchetii and $P$. globosa (see paragraph below), most marine ecologists until the mid 1990s followed Sournia's advice and reported Phaeocystis colonies as $P$. pouchetii (the older name) or as Phaeocystis sp. to avoid confusion.

Baumann and Jahnke (1986), Jahnke and Baumann $(1986,1987)$ and Jahnke (1989) regarded this as over-simplification. Their observations on colony shape maintenance in long term culture showed that both juvenile and older stages of $P$. globosa and $P$. pouchetii were distinct and these data supported the recognition of the two entities as separate species. Also, detailed studies of the temperature and light tolerances suggested separation at the species level. P. globosa was a temperate species and $P$. pouchetii was a cold-water form. A third, unnamed colonial species from Antarctic waters was recognized by Baumann et al. (1993), which had a combination of features of $P$. globosa and pouchetii, as suggested earlier by Moestrup and Larsen (1992). The colonies resembled those of $P$. globosa (Larsen and Moestrup 1989), whereas temperature tolerance was similar to that of $P$. pouchetii. Notably, strains from the Antarctic had different pigment spectra (Buma et al. 1991; Vaulot et al. 1994) and DNA content (Vaulot et al. 1994). First indications that further undescribed species could exist were provided by Pienaar $(1991,1996)$ who illustrated a Phaeocystis flagellate with cup-shaped scales from South African waters suggesting it was a new species but not publishing a formal description.

To resolve the species issue in Phaeocystis, a molecular analysis of various clones was begun (Lange 1997). Medlin et al. (1994) were the first to propose that $P$. globosa and $P$. pouchetii were separate species based on genetic evidence. They also showed that colonial Phaeocystis from the Antarctic was genetically distinct from the other two species. They resurrected the species $P$. antarctica described by Karsten (1905) for the colonial isolates previously termed $P$. globosa or pouchetii from these waters. Zingone et al. (1999) added two more species to the genus, $P$. cordata and $P$. jahnii, but these were basically unicellular species, although the latter species could make simple clusters of cells that could be termed colonial. In this review we summarize the molecular and morphological information available to date for Phaeocystis species and provide evidence that a high diversity is still hidden in the genus.

\section{Molecular analysis}

A global distribution of the prymnesiophyte genus Phaeocystis was compared using nuclearencoded 18S rDNA genes and two non-coding regions, the ribosomal DNA internal transcribed spacer 1 (ITS1) separating the $18 \mathrm{~S}$ rDNA and 5.8S rDNA genes and the plastid ribulose-1,5-bisphosphate carboxylase/oxygenase (RUBISCO) spacer flanked by short stretches of the adjacent large and small subunits ( $r b c L$ and $r b c S$ ) (Lange et al., 2002). The RUBISCO spacer regions were highly conserved and generally uninformative among all Phaeocystis strains (Lange et al. 2002). The 18S rDNA analysis suggests that an undescribed unicellular Phaeocystis sp. (isolate PLY559) is a sister taxon to the occasionally colonial Mediterranean $P$. jahnii with which it forms a clade that diverges at the same time from a clade with all other Phaeocystis species, including those forming typical colonies wrapped in a skin (Fig. 1). In this latter clade, the unicellular P. cordata diverges before the colonial ones, which can be divided into a cold-water complex $(P$. pouchetii from the Arctic and P. antarctica from the Antarctic) and a warm-water complex consisting of $P$. globosa. Thus, all of the variation seen earlier using morphological and physiological criteria had a strong genetic basis and separation at the species level was warranted for all colonial species originating from major climatic regions, i.e., the Arctic, the Antarctic and temperate/tropical regions.

In contrast, ITS1 exhibited substantial interand intra-specific sequence divergence and showed more resolution among the strains (Fig. 2). Markedly different copies of the ITS1 
Fig. 1 Maximum-likelihood phylogeny (fastDNAml) of 17 Phaeocystis species/strains and other prymnesiophytes inferred from $18 \mathrm{~S}$ rDNA. The class Pavlovophyceae was used as outgroup. Bootstrap values are placed on the nodes that are identical from ML/NJ/MP analyses. to two base changes per 100 nucleotides. Redrawn from Lange et al. (2002) The scale bar corresponds

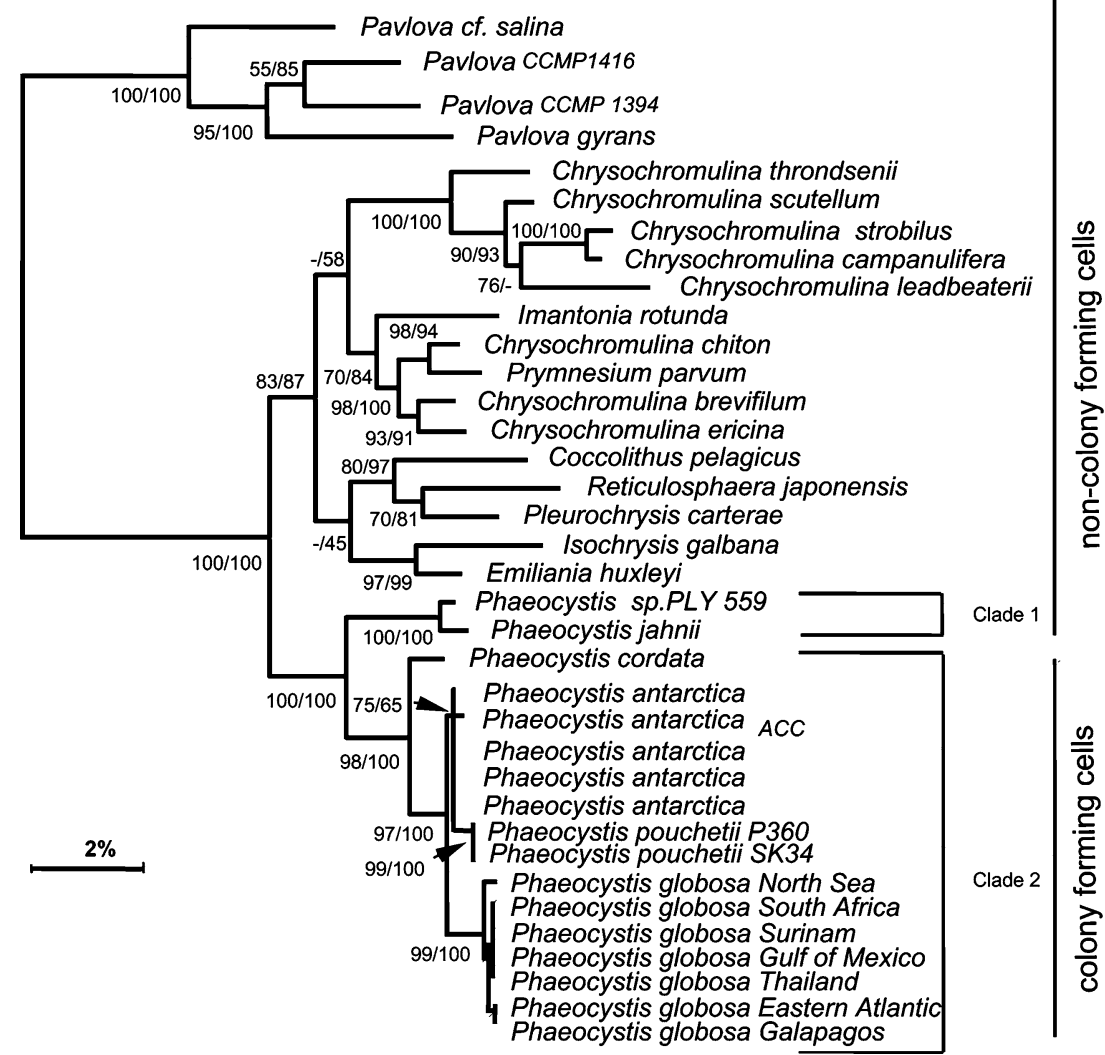

region were found in $P$. globosa even among cloned DNA from a single strain, suggesting that it is a species complex composed of at least three species. This observation was also supported by different DNA content among different clones of Phaeocystis (Vaulot et al. 1994). Multiple copies of the ITS1 were also found in a single strain of $P$. pouchetii, suggesting that this is also a species complex. These species complexes would appear still to be able to interbreed with one another because multiple different haplotypes from different clades can be found within a single strain. Similar findings of multiple haplotypes being present in known hybrids of flowering plant species are quite common (Chase et al 2003) and it is known that in some hybrids of flowering plants, the hybrid can loose one of the parental haplotypes in as few as 12 generations (Bateman, pers. com.) However, among nine $P$. antarctica strains, only one type of ITS1 haplotype was found per strain, although it was variable among the strains. Using the branching order in the ITS1 tree (Fig. 3) we have attempted to trace the biogeo- graphic history of the dispersal of strains in Antarctic coastal waters. We see that the first divergence among the Antarctic clade is strain SK 22, which was isolated from the Antarctic circumpolar current (ACC). The second divergence is a strain from Prydz Bay (T4-2) and this is then folremaining strains. Among these divergences is a cluster of strains from Prydz Bay (DE2, A1-3 and T9-1). The other divergence includes strain CCMP 1374 from the Ross Sea and two Phaeocystis strains from the Weddell Sea (SK 20, SK 23) (Fig. 3) and finally strain D4-5 from Prydz Bay, which shares a last common ancestor with the Weddell Sea strain SK 23, as the final cluster to diverge among the Antarctic strains. Populations of $P$. antarctica within the continental boundary water masses appear to be well-mixed because currents move around the Antarctic continent rather quickly and may effectively act as a barrier to significant population structure. Strain SK 22 isolated within the ACC, however, is clearly different. An earlier hypothesis, proposed lowed by a nearly simultaneous divergence of the 
Fig. 2 Maximum-likelihood phylogeny of the ITS regions showing the multiple sequences from a single strain of $P$. globosa and $P$. pouchetii. Each different sequence comes from a different bacterial vector clone. All haplotypes from one strain of Phaeocystis are connected by the arrows. $P$. antarctica exhibited a single sequence per strain and these are collapsed into a triangle. Redrawn from Lange et al. (2002)

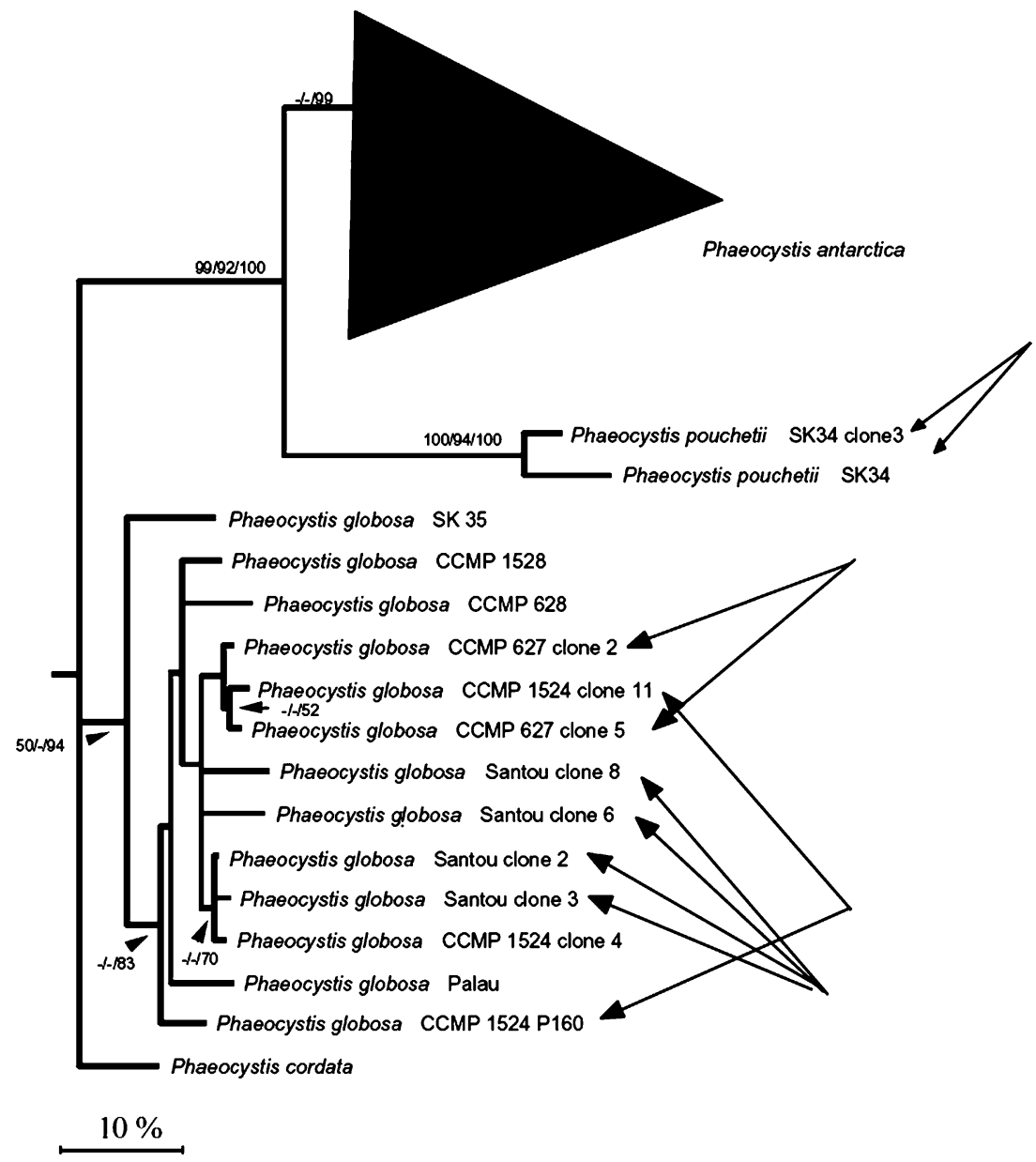

from rDNA data (Medlin et al. 1994), that ancestral populations in the Antarctic gave rise to present day $P$. antarctica and $P$. pouchetii populations appears to be supported by ITS1 analysis of the cold-water Phaeocystis strains. P. antarctica and $P$. pouchetii, both polar, are more closely related to one another than either is to the cold and warm temperate to tropical populations of present-day $P$. globosa. This suggests that dispersal did not occur from present-day warm-water populations into present-day cold-water populations but that gene flow has occurred from pole to pole across tropical oceans. Arctic P. pouchetii populations thus probably arose by a dispersal event from the south to the north during colder climate periods that allowed populations to survive the crossing of equatorial waters, as has been documented for other organisms (Crame 1993; Darling et al. 2000, 2004; Montresor et al. 2003). A subsequent warm- ing event will then isolate the two polar populations. Evidence for this can be found in a study of Antarctic surface-water temperatures since the Cretaceous (Crame 1993, Fig. 4c).

If we follow the branching order in Fig. 1, we hypothesize the following scenario: Phaeocystis likely originated as a warm-water genus because first divergences in our tree are warm-water species. Ancestral populations in the Antarctic were derived from ancestors of the present-day warmwater species, after being isolated in Antarctic waters. The opening of the Drake passage and the formation of the Antarctic circumpolar current (ACC) are the most likely geological events that could have isolated populations in the Antarctic to separate them from warm-water ancestors. It can be inferred from Fig. 3 that presumed descendants of these warm-water ancestors were first entrained in the ACC because these are the first 

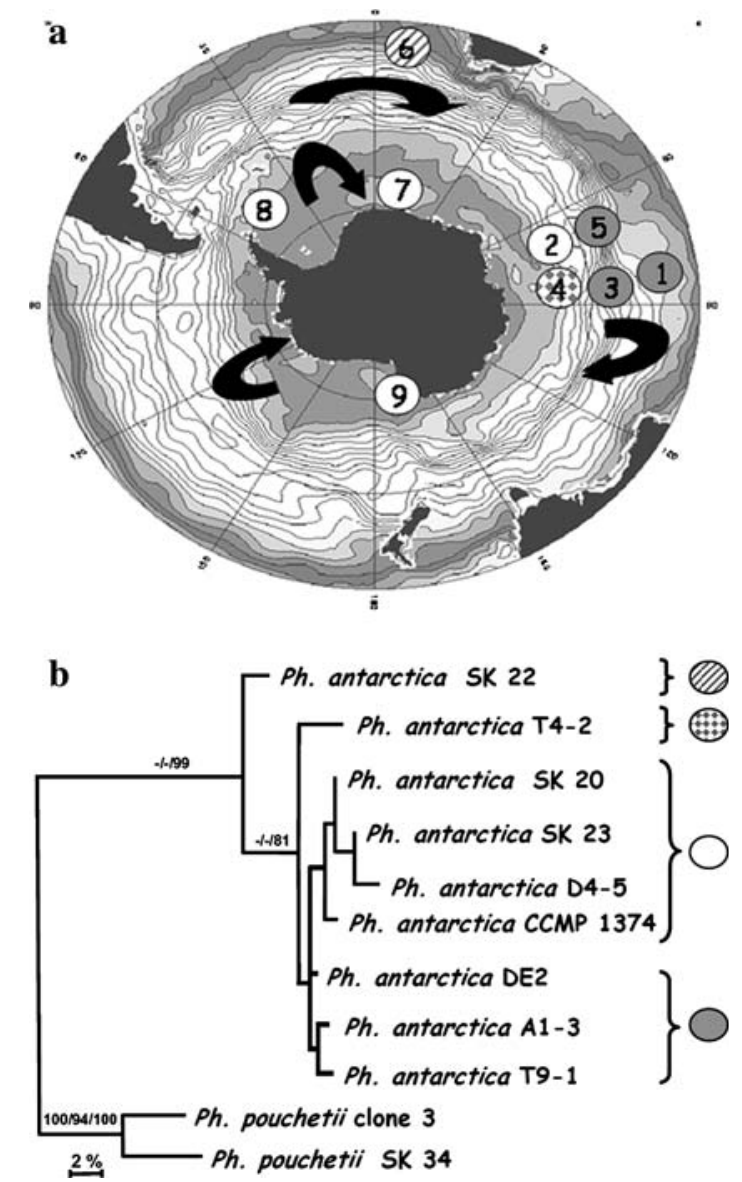

Fig. 3 (a) Locations of the strains of $P$. antarctica used in Lange et al. (2002). The location of different clades is indicated by the different patterns in the large circles and correspond to those clades in (b). Prydz Bay locations in E. Antarctica are slightly displaced for visual clarity. (b) Maximum-likelihood tree inferred from ITS1 sequences from $P$. antarctica with $P$. pouchetii as outgroup. Bootstrap values are placed at the nodes from a maximum likelihood analysis (100 replicates) a neighbor-joining analysis (500 replicates) and a maximum parsimony analysis (500 replicates). The scale bar corresponds to two changes per 100 nucleotide positions. Redrawn from Lange et al. (2002). Map of Antarctica redrawn from Olbers et al. (1962)

divergences. Some of these ancestral populations must have been transported northward and across the Equator shortly after the Drake passage opened because the $P$. pouchetii populations are sister to the $P$. antarctica populations. The ACC today encircles the Antarctic continent every 1-2 years. Water is entrained from this current into the major gyres of the continental water masses (Treshnikov 1964). Using the branching order in
Fig. 3 we can trace the dispersal of the clones from the ACC, although the bootstrap support for the branching order is weak to strong among the clades. The first entrainment with a bootstrap support of $99 \%$ appears to be into Prydz Bay because strain T4-2 isolated from this bay is the first divergence in our tree. These populations then established themselves in the Eastern Antarctic in Prydz Bay. Subsequent divergences in the tree indicate that populations were then entrained into the Ross Sea and almost simultaneously they were entrained into the Weddell Sea (bootstrap support 54\%). Both isolates from the Weddell Sea were the last to diverge before the populations were again entrained back into Prydz Bay from populations in the Weddell Sea because isolates from this bay are some of the last divergences in the tree (bootstrap 54\%). The distribution of these isolates in this fashion follows the predominant current patterns of surface waters in the Antarctic today. What we do not know is how different the surface-water circulation was $30 \mathrm{Ma}$ before the ACC was established.

Other studies have also shown the effect of mixing on the homogenization of the genetic structure of Antarctic populations. Krill species within the Antarctic continental water masses are very similar as documented by both mtDNA (Patarnello et al. unpubl.) and isozyme analysis (Fevolden and Schneppenheim 1989). The mtDNA study also suggested that the formation of the ACC effectively isolated krill species in Antarctic water masses from those north of the ACC. Calculation of the time of divergence between species groups found either side of the ACC coincided with the timing of the ACC, approximately $30 \mathrm{Ma}$. Thus, the molecular data is consistent with our hypothesized historical biogeographic reconstruction of the distribution of Phaeocystis based on the circulation patterns developed with the formation of the ACC.

\section{Molecular clock}

A molecular clock has been constructed from our $18 \mathrm{~S}$ rDNA tree and calibrated with fossil dates from the haptophyte coccolithophorid species (Fig. 4). Our molecular clock calculations indicate 


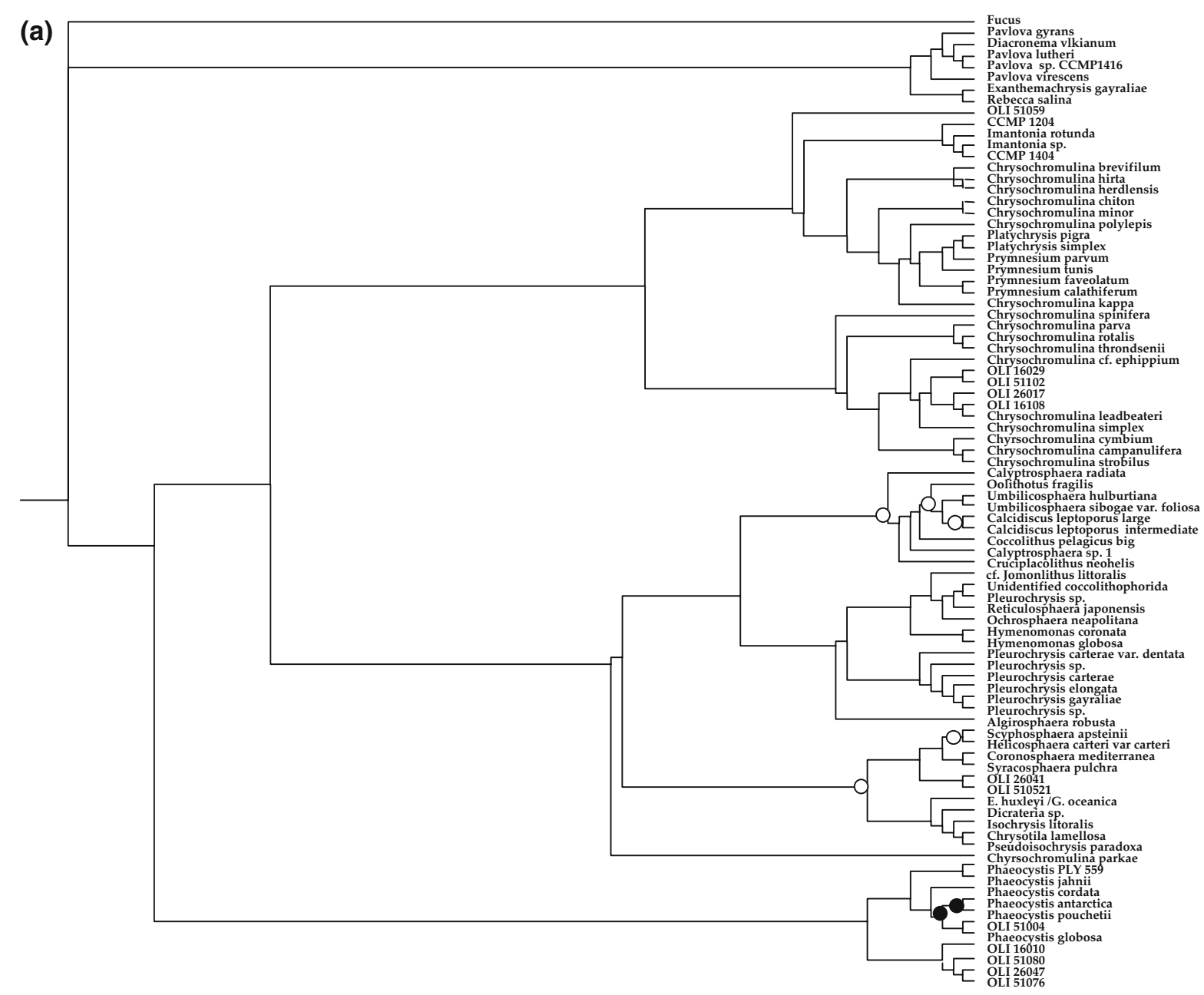

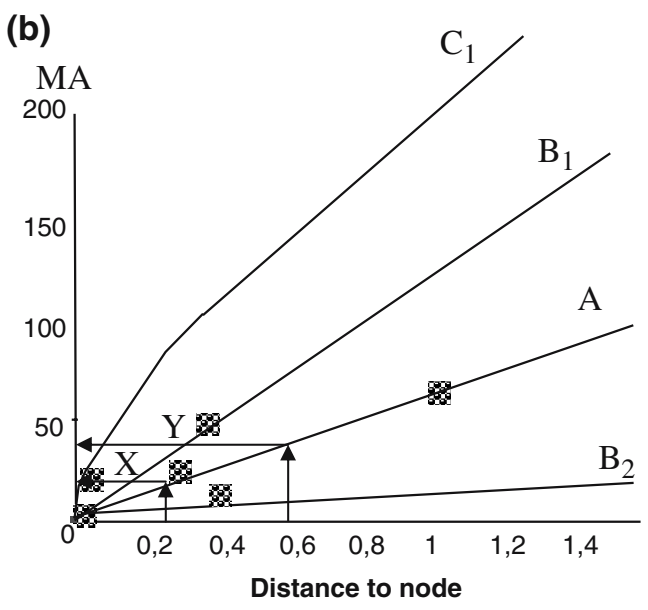

Fig. 4 Calculation of a molecular clock. (a) The $\mathrm{ml}$ tree shown in Edvardsen et al. (2000) has been linearized (Kooistra and Medlin 1996) so that all rates of evolution are the same. Fossil dates from coccolithophore taxa are placed on nodes where these taxa have their first appearance in the fossil record (open circles on tree). (b) A regression of branch lengths against fossil dates has been performed

(c)

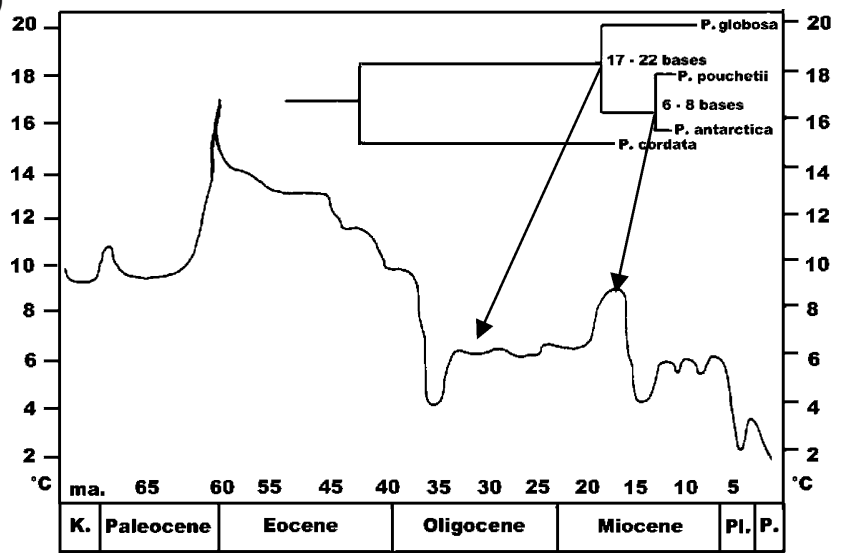

according to Kooistra and Medlin (1996). From this regression line we have extrapolated the divergence of the warmand cold-water Phaeocystis (Y) and the divergence of $P$. pouchetii from $P$. antarctica $(\times)$ (solid circles on tree). (c) Temperature of Antarctic surface waters since the Cretaceous with the molecular tree plotted proportional to the time and the temperature, redrawn from Crame (1993) 
that the warm-water Phaeocystis species diverged from the cold-water species approximately $30 \mathrm{Ma}$, which coincides with the time that the Drake passage opened and the ACC system was formed. This would have effectively isolated ancestral populations in the Antarctic sufficiently to allow them to speciate from their warm-water ancestors. The separation of $P$. pouchetii from $P$. antarctica is approximately $15 \mathrm{Ma}$, which coincides with a major warming event in the world's oceans at this time (Fig. 4). Before this time populations must have been able to cross the equator from the south to the north because water temperatures were cool enough to allow survival, but this warming event separated the two polar populations to allow them to diverge into the two species we have today at the poles. Similar results have been found for foraminfera (Darling et al. 2000, 2004).

Thus molecular data have defined our species well and suggest which species are likely to be composed of cryptic species. We detail below basic descriptions of each of the formally described species and provide some indication as to other undescribed species where this information is known.

\section{Formally described species}

An overview of the validly published taxa that have been re-examined in recent years is presented in the following. These include species listed in the genus in its most recent review (Sournia 1988) and new species described after that date, with the exception of three taxa that have not been studied since their description, P. amoeboidea Büttner, $P$. sphaeroidea Büttner and $P$. brucei Mangin. The first two of these do not have features characteristic of the genus, much the division Haptophyta, so it is likely that only the latter species may still be a valid species of Phaeocystis. The main distinctive characters of the species included in this section are summarized in a table in Jacobsen (2002).

P. pouchetii (Hariot in Pouchet) Lagerheim (Pouchet 1892) forms cloud-like colonies with cells in packets of four (Fig. 5a). Molecular data suggest that this is a species complex but here very few strains have been examined with molecular techniques so this is only a very preliminary suggestion.

Flagellated stages of $\boldsymbol{P}$. pouchetii (Fig. 6a) were the subject of recent morphological studies (Jacobsen 2000, 2002). Cells are rounded, with an average diameter of $5 \mu \mathrm{m}$. The flagella are equal in length, ca $11 \mu \mathrm{m}$, and heterodynamic. The haptonema is extremely short, 1-2 $\mu \mathrm{m}$, with a slight swelling, and is not easily seen with light microscopy. Body scales are of two types: almost circular flat plates, $0.24 \times 0.25 \mu \mathrm{m}$, with raised rims, forming an external layer and smaller oval plates with slightly inflexed rims, $0.19 \times 0.15 \mu \mathrm{m}$, underneath the larger scales. Both types of scales show thin radiating ridges. Filaments (up to $30 \mu \mathrm{m})$ arranged in groups of five with the typical pentagonal proximal structure are seen outside the cells, or are coiled up in vesicles under the cell surface. The presence of silica is reported in these filaments (Jacobsen 2002). The ultrastructure is similar to that of P. globosa (Parke et al. 1971) and of the other Phaeocystis for which this information is available (Zingone et al. 1999), with the nucleus located posteriorly, the two chloroplasts with the embedded pyrenoids, and the Golgi body between them. This cell stage can be infected by viruses (Jacobsen et al. 1996).

P. globosa Scherffel (Scherffel 1900) forms globular colonies with the cells evenly distributed throughout the colony (Fig. 5b). Molecular data and DNA content suggest that this is a complex of up to three or four cryptic species, but to date no morphological investigations exist to support this.

Flagellated stages of $\boldsymbol{P}$. globosa (Fig. 6b, c) were described for the first time by Parke et al. (1971) under the name of $P$. pouchetii, at the time when these two species were considered as stages within the life cycle of the same species. Cells are 3-6 $\mu \mathrm{m}$, more frequently between 3 and $4.5 \mu \mathrm{m}$. The two flagella and the haptonema emerge from a depression in the cell body. Flagella are equal in length, $1.5 \times$ the cell length, and heterodynamic. The haptonema is a quarter to a third the length of the flagella. It is stiff and has a clear distal swelling. The haptonema is easily seen in live cells, where it is directed forward while cells move. Body scales show all radiating ridges on both surfaces and are of two types: almost circular flat plates, $0.18 \times 0.19 \mu \mathrm{m}$, with raised rims, forming 

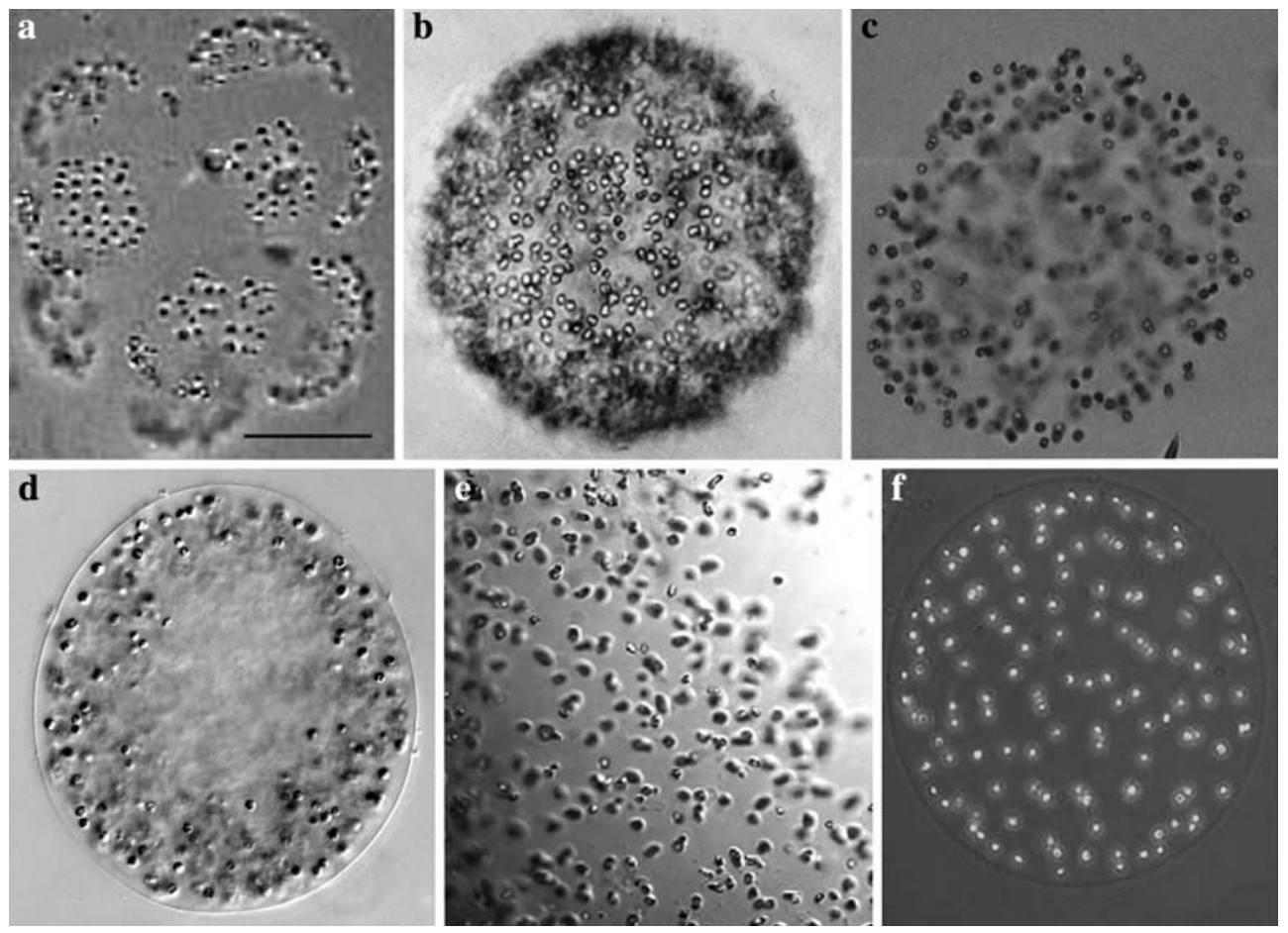

Fig. 5 Light microscopic micrographs of colony stages of Phaeocystis. (a) P. pouchetii, (b) P. globosa, (c) P. antarctica, young colony, (d) $P$. antarctica, older colony, (e) $P$. jahnii, (f) Phaeocystis sp.2 (a, b) taken from http://www.jochemnet.de/fiu/OCB3043_21.html Scale bar $=100 \mu \mathrm{m}$

point of view. It also forms globular colonies with cells randomly distributed under the colony surface (Fig. 5c, d). These colonies can become quite distorted and elongated with age.

Flagellated stages of $\boldsymbol{P}$. antarctica (Fig. 6d) have received very little study. Only one illustration of scales from an Antarctic Phaeocystis was available (Larsen and Moestrup 1989), showing oval scales of two different sizes $(0.27 \times 0.19 \mu \mathrm{m}$ and $0.18 \times 0.14 \mu \mathrm{m}$, respectively). Recently, three different morphs have been illustrated from field material from the Antarctic having scales that are different in size as compared to those shown by Larsen and Moestrup and having a haptonema without a bulge on its tip (Marchant et al. 2005, Figs. 6f, 7d-f). Scales of still different sizes have been detected in flagellated stages obtained from the isolation of colonies, which are phylogenetically close to SK 22 (Zingone and Montresor, unpublished). The molecular data published to date are derived only from colonial stages or from flagellate stages that were originally colonial. There is only a single type of ITS sequence pres-
$\boldsymbol{P}$. antarctica Karsten (Karsten 1905) is the least known Phaeocystis from the morphological 

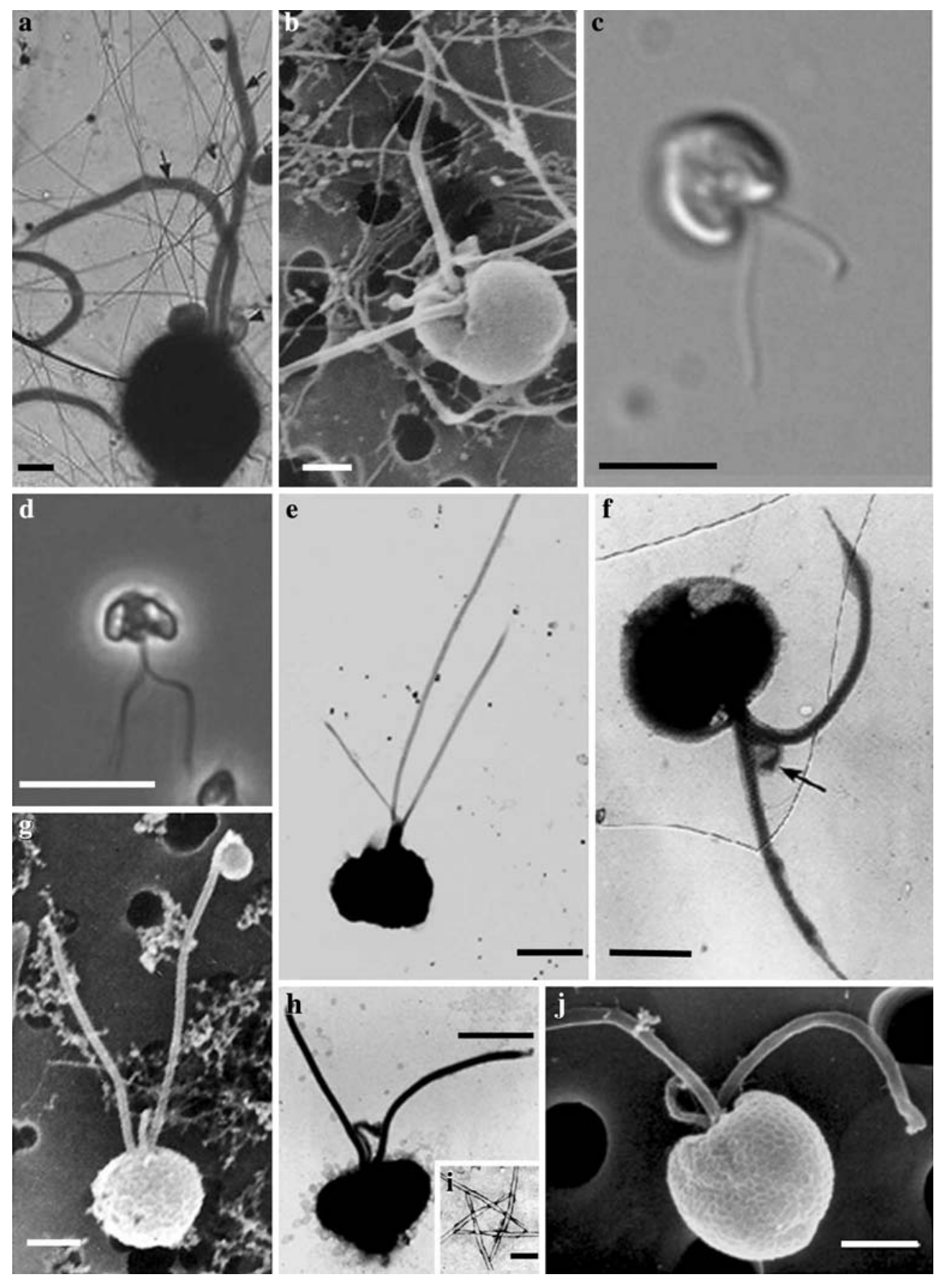

Fig. 6 Light microscopy (LM), transmission electron microscopy (TEM) and scanning electron microscopy (SEM) micrographs of flagellated stages of Phaeocystis. (a) P. pouchetii, TEM, (b) P. globosa, SEM, (c) P. globosa, LM, (d) P. antarctica, LM, (e) P. jahnii, TEM, (f) Phaeocystis sp. from Antarctic waters TEM, (g) Phaeocystis sp. 3, SEM, (h) P. cordata TEM, (i) P. cordata, star-like pattern in the center of the five-filament structure, TEM, (j) P. cordata, SEM. (a) from Jacobsen (2002), (c) taken by Anna Noordeloos, (d) taken by Dr. P. Assmy, (f) from Scott and Marchant (2005), (e, h, i) from Zingone et al. (1999), (b) and (g) from Vaulot et al. (1994). Scale bar $=1 \mu \mathrm{m}$ on $(\mathbf{a}, \mathbf{b}$, g) Scale bar $=10 \mu \mathrm{m}$ on (c, d) Scale bar $=2 \mu \mathrm{m}$ on $(\mathbf{e}-\mathbf{j})$ Scale bar $=0.3 \mu \mathrm{m}$ on $(\mathbf{i})$ 

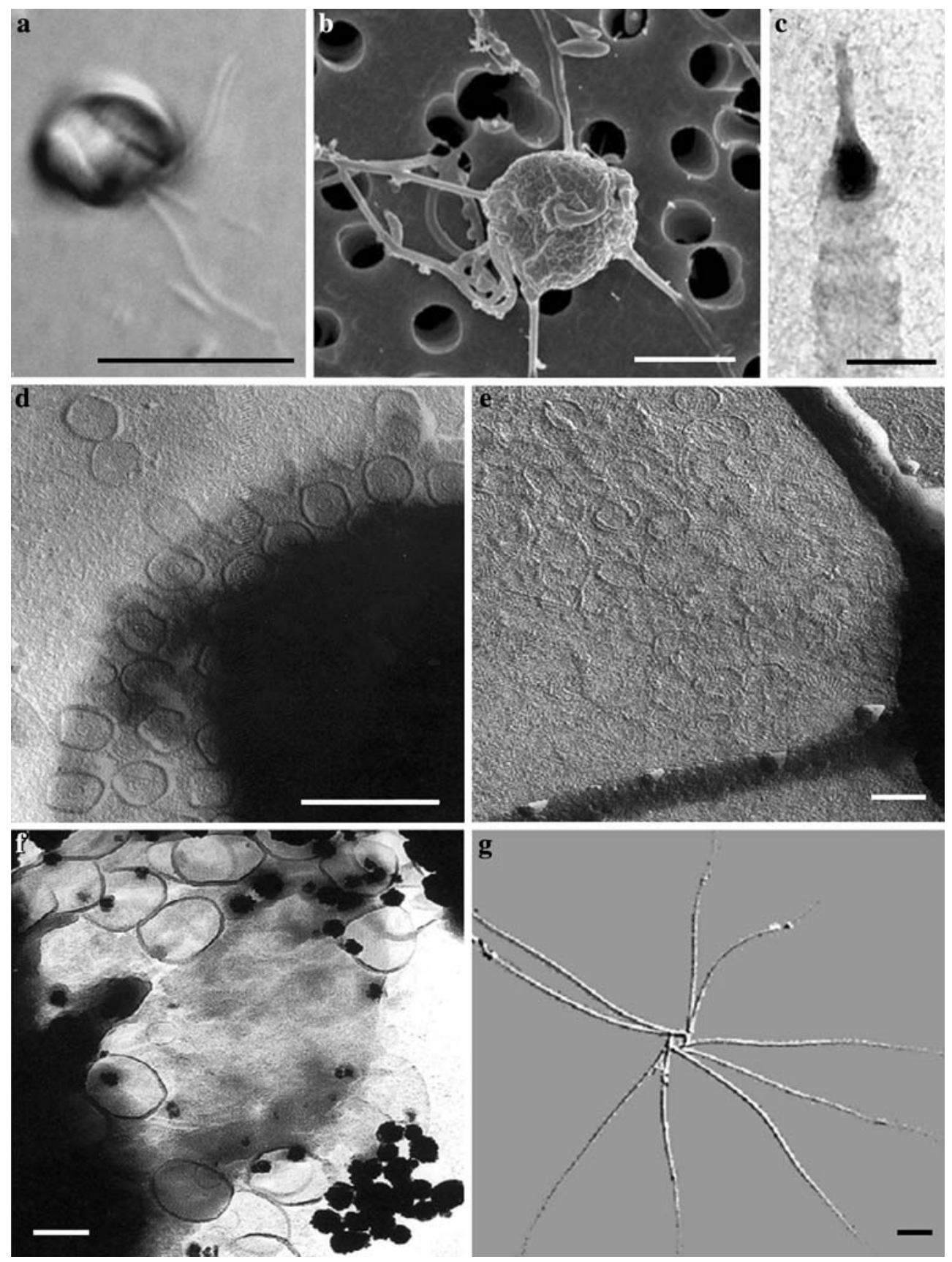

Fig. 7 LM, TEM and SEM micrographs of flagellated stages of Phaeocystis. (a) Phaeocystis sp. 1 (PML 559), LM, (b) Phaeocystis sp. 1 (PML 559), SEM, (c) Tip of the tube-like structure ejected from Phaeocystis sp. 1 (PML 559), TEM. (d-f) Morphs 1, 2, 3 of $P$. antarctica, (g) filaments of $P$.

ent in each strain in contrast to the multiple ITS variants in $P$. pouchetii and $P$. globosa, which strongly suggests that colonial Phaeocystis from the Antarctic are not a species complex. The similarity scrobiculata, $(\mathbf{b}, \mathbf{c})$ taken by Gandi Forlani, $(\mathbf{d}-\mathbf{f})$ from Scott and Marchant (2005). (g) From www.marbot.gu.se/SSS/ others/Phaeocystis_scrobiculata.GIF. Scale bar $=10 \mu \mathrm{m}$ on (a) Scale bar $=2 \mu \mathrm{m}$ on $(\mathbf{b}),(\mathbf{g})$ Scale bar $=0.5 \mu \mathrm{m}$ on $(\mathbf{c}-\mathbf{f})$

among ITS sequences from Antarctic strains indicates that they could be all a single species, whereas these new unicellular morphs in field samples may belong to species as yet uncultivated 
(Fig. 7d-f). Alternatively, different flagellate morphotypes could belong to different sub-clades in the $P$. antarctica-clade. All this information indicates a high morphological diversity and suggests that there might be more than one species present in Phaeocystis from the Antarctic. Parallel morphological investigations are warranted on strains belonging to distinct $P$. antarctica sub-clades.

$\boldsymbol{P}$. jahnii Zingone (Fig. 5e) forms colonies very different from all other Phaeocystis colonies (Zingone et al. 1999). These are loose aggregates of non-motile cells embedded in a sticky mucilaginous matrix probably of polysaccharide nature, with no external layer nor a definite shape. In culture material the colonies may form wide sheets with margins at times sticking to the cell tube. Colonial cells range from 6 to $8.5 \mu \mathrm{m}$ and have 24 chloroplasts.

Flagellated cells of $\boldsymbol{P}$. jahnii (Fig. 6e) are rounded, 3.5-5 $\mu \mathrm{m}$ diameter, with flagella of markedly unequal length $(8.5-12 \mu \mathrm{m}$ and 5.5-6.5 $\mu \mathrm{m}$, respectively). The haptonema is relatively long $(3-4.5 \mu \mathrm{m})$ and without a marked bulge at the end. As compared to the other Phaeocystis species, scales are thinner and more delicate, with a very faint radiating pattern lacking in the central part of the scale. The larger scales $(0.35 \times 0.28 \mu \mathrm{m})$ do not have an upraised rim, whereas the smaller underlying scales $(0.18 \times 0.14 \mu \mathrm{m})$ have the typical inflexed rim. A refringent yellow-orange body is often seen in the live cells in the space between the chloroplasts. Filaments have not been observed in this species.

$\boldsymbol{P}$. cordata Zingone et Chrétiennot-Dinet (Fig. 6h-j) occurs only as single cells which are typically triangular, heart-shaped or oval, somewhat flattened, with a deep flagellar depression and more or less pointed antapical end (Zingone et al. 1999). The average size is $3-3.5 \mu \mathrm{m}$ long, 3-4 $\mu \mathrm{m}$ wide, and ca. $2.5 \mu \mathrm{m}$ thick. The two flagella are slightly subequal, 5.5-7.5 and 4.5-6 $\mu \mathrm{m}$ length, respectively. The haptonema is very short $(2.2-2.5 \mu \mathrm{m})$ and hardly visible in light microscopy, with a bulging end observed in the electron microscope. Cells generally swim with the flagellar pole directed backwards, and the two flagella straight, completely hiding the haptonema. Cells rotate around their longitudinal axis while moving. Rarely cells are seen moving with the flagellar pole forward. Both larger and smaller scales are oval, $0.25 \times 0.18 \mu \mathrm{m}$ and $0.18 \times 0.13 \mu \mathrm{m}$, respectively. The larger scales have upraised rims and a slight central knob, and form the external cell investment. The smaller scales have inflexed rims and form an inner layer adjacent to the plasmalemma. The filaments are seen in disk-like vesicles underneath the cell surface (up to three in a cell) or discharged, with the typical five-ray star pattern (Fig 6i). Ultrathin sections show the two flagella and the haptonema inserted along a line that is transversal to the plane crossing the plastids. Comparable information is not available for other species yet. The internal microanatomy is similar to that of the other species of the genus.

P. scrobiculata Moestrup (Fig. 7g) was described from field material collected in New Zealand waters (Moestrup 1979) as a unicell. There is no evidence that it makes colonies nor any molecular work has been done on it. Its cells are $8 \mu \mathrm{m}$ in diameter with two types of scales, $0.6 \times 0.45 \mu \mathrm{m}$ and $0.19 \times 0.21 \mu \mathrm{m}$ in size. Both types of scales are structureless on the dorsal side, but with ridges radiating from a plain centre on the ventral side. Its flagella and haptonema are twice the length found in $P$. globosa and the scales are about two times larger. Another distinguishing feature is the filaments that it produces, which are in groups of nine (eight pairs and one single), in contrast to the production of five single filaments from the other species that produce filaments (Fig. $7 \mathrm{~g}$ ). The centre pattern of the filaments is rather irregular and does not form the characteristic star shape in the middle. Filaments arranged with the same pattern have also been found in Australian waters (Hallegraeff 1983) and in the Mediterranean Sea (Zingone et al. 1999). However, scales were smaller in both Australian and Mediterranean specimens, which suggests a possible higher diversity to be explored within this taxon as well.

\section{Undescribed species}

In addition to the species described in the literature, a number of taxa ascribed to Phaeocystis that are currently under morphological and molecular investigation are presented in the following. 
Phaeocystis sp. 1 (PML 559) (Fig. 7a-c) seems only to be present in single cells. The two flagella are $8.5-12 \mu \mathrm{m}$ and $5.5-6.5 \mu \mathrm{m}$, respectively. The haptonema is $3-4.5 \mu \mathrm{m}$ long, without a bulge at the end. The larger scales are similar to those of $P$. cordata, though larger (ca. $0.35 \times 0.22 \mu \mathrm{m}$ ), with thick upraised rim and a central knob. Smaller scales $(0.25 \times 0.17 \mu \mathrm{m})$ have inflexed rims. An unusual feature of this species is that it produces tube-like structures with peculiar ends that are ejected from the cell. These bodies may be present in number of 5-7 per cell (Fig. 7b) and leave a large depression once extruded. Many benthic stages are formed as the culture ages and it is likely that the tube-like bodies help to attach the cells to the substrate.

Phaeocystis sp. 2 (Fig. 5f) is the only Phaeocystis so far cultivated from the Mediterranean Sea that has been shown to form typical colonies of spherical shape (Zingone, Borra, Forlani and Procaccini, in preparation). The flagellates have an irregular shape, with pronounced shoulders at the flagellar pole. The flagella are markedly unequal in length, the haptonema has no bulging end. No scales were ever detected on the cell surface, nor any kinds of filaments. $18 \mathrm{~S}$ analyses demonstrate that this taxon belongs to the P. globosa clade, although it differs by nine base pairs, a difference that is comparable to that between $P$. pouchetii and $P$. antarctica. ITS sequence is unalignable with those of those available for the other P. globosa strains.

Phaeocystis sp. 3 (Fig. 6g) includes strains isolated from the North-Western Mediterranean Sea. Being single-celled and similar to $P$. cordata in scale morphology, it was preliminarily attributed to the latter species (as strains MEDNS2 and MEDNS3 in Zingone et al. 1999), but it has morphological differences that were initially unappreciated. As compared to $P$. cordata, Phaeocystis sp. 3 is somewhat larger, has a rounded body, shorter flagella and the larger body scales are almost circular rather than oval. Preliminary molecular analysis has placed it within the P. globosa complex.

Clearly, morphological details of the species encountered in recent years fall outside of the original description of the genus Phaeocystis, therefore we feel it necessary to emend the genus description as follows:
Phaeocystis Lagerheim 1893, Zingone and Medlin emended.

Motile cells with two more or less equal flagella and a shorter non-coiling haptonema; 1-4 parietal chloroplasts; cell body often covered with flat scales of two different sizes. Ejectile organelles known for several species. Complex life cycles involving the formation of non-motile stages, not known for all species. Non-motile cells usually without appendages and scales, either single or arranged in spherical, lobed, sheathed or irregular gelatinous colonies; if appendages present, usually shorter or incomplete.

\section{Outlook}

From the observations we have to date, including field and cultured material and molecular data, it is clear that we have come a long way from just 10 years ago, when we had only one species of Phaeocystis: P. globosa with a cosmopolitan distribution. We now have a much clearer picture of the species in the genus and their distribution. However Phaeocystis still holds many mysteries. Clearly, there are more species of Phaeocystis than presently formally recognized. Some of these are morphologically distinct, whereas others require further research to assess whether they are cryptic species or, rather, they are morphologically distinct at least in some stages of their life cycle. New avenues of molecular and morphological investigation concern the taxa known only from field material, such as the three morphotypes of $P$. antarctica, and the as yet uncultured and rare $P$. scrobiculata, or the flagellate with cup-shaped plates from South African waters (Pienaar 1991, 1996). As flagellate stages appear to be more widespread and diverse as compared to colonial stages, material to study should be gathered through specific cultivation techniques (e.g., serial dilution techniques). Whereas the function of the thin filaments has not been fully clarified, the role of the peculiar extrusomes found in PLY 559 is even more difficult to understand. Presumably these are different attachment mechanisms, but they could also be involved in potential overwintering stage formation (Gäbbler et al. unpublished observations). The molecular 
tools that have been used so far have significantly contributed to delineate Phaeocystis species. What remains to be clarified is the genetic diversity within the major species and how this diversity changes in time and space, which will require the set up of new high-resolution methods (see Gäbbler et al. (2007)) for the latest developments in population genetic analysis of Phaeocystis). This information, coupled with a better circumscription of species, is the prerequisite for significant advancements in the understanding of the ecology of one of the key players of the world ocean's plankton.

Acknowledgements Dr. Philipp Assmy kindly provided photographs of $P$. antarctica. Gandi Forlani provided photographs of Phaeocystis sp. 1 (PML 559). Photographs taken from Fig. 5.2 from Scott and Marchant (2005) were reproduced with permission from F.J. Scott and H.J. Marchant (Eds), Antarctic Marine Protists 258, (2005), Copyright Australian Biological Resources Study, Australian Antarctic Division and Andrew Davidson. Figures reproduced from 'Morphology, relative DNA content and hypothetical life cycle of Phaeocystis pouchetii (Prymnesiophyceae); with special emphasis on the flagellated cell type' by Jacobsen (2002) from Sarsia, www.tandf.no/sarsia, 2002, 87: 338-349, by permission of Taylor and Francis AS. Figures 2a, g in Vaulot et al. (1994) and Fig. 6, 9, 32 in Zingone et al. (1999) were reproduced with permission of the Phycological Society of America. This review falls within the scopes of the EU Network of Excellence MARBEF (Marine Biodiversity and Ecosystem Functioning).

\section{References}

Bätje M, Michaelis H (1986) Phaeocystis pouchetii blooms in the east Frisian coastal waters (German Bight, North Sea). Mar Biol 93:21-27

Baumann MEM, Jahnke J (1986) Marine Planktonalgen der Arktis. I. Die Haptophycee Phaeocystis pouchetii. Mikrokosmos 75:262-265

Baumann MEM, Brandini FP, Staubes R (1993) The influcence of light and temperature on carbon specific DMS-release by cultures of Phaeocystis antarctica and three Antarctic diatoms. Mar Chem 45:56-78

Baumann MEM, Lancelot C, Brandini FP, Sakshaug E, John DM (1994) The taxonomic identity of the cosmopolitan prymnesiophyte Phaeocystis: a morphological and ecophysiological approach. J Mar Syst 5:23-39

Buma AGJ, Bano N, Veldhuis MJW, Kraay GW (1991) Comparison of the pigmentation of two strains of the prymnesiophyte Phaeocystis sp. Neth J Sea Res 27:173-182

Büttner J (1911) Die farbigen Flagellaten des Kieler Hafens. Wiss Untersuch, NF Abt Kiel 12:119-133
Chang FH (1983) The mucilage producing Phaeocystis pouchetii (Prymnesiophyceae) cultured from the 1981 'Tasman Bay slime'. N Z J Mar Freshw Res 17:165-168

Chrétiennot-Dinet MJ, Giraud-Guille M-M, Vaulot D, Putaux J-L, Saito Z, Chanzy H (1997) The chitinous nature of the filaments ejected by Phaeocystis (Prymnesiophyceae). J Phycol 33:666-672

Crame JA (1993) Latitudinal range fluctuations in the marine realm through geological times. Trends Ecol Evol 8:162-166

Chase MW, Knapp S, Cox AV, Clarkson JJ, Butsko Y, Joseph J, Savolainen V, Parokonny AS 2003. Molecular systematics, GISH and the origin of hybrid taxa in Nicotiana (Solanaceae). Ann Bot 92:107-127

Darling KF, Wade CM, Stewart IA, Kroon D, Dingle R, Brown AJL (2000) Molecular evidence for genetic mixing of Arctic and Antarctic subpolar populations of plankton foraminifers. Nature 405:43-47

Darling KF, Kucera M, Pudsey CJ, Wade CM (2004) Molecular evidence links cryptic diversification in polar planktonic protists to Quaternary climate dynamics. PNAS 101:7657-7662

Davidson AT (1985) Aspects of the biology of Phaeocystis pouchetii (Prymnesiophyceae) (Hons. Thesis). University of Tasmania

Davidson AT, Marchant H (1992) The biology and ecology of Phaeocystis (Prymnesiophyceae). In: Round FE, Chapman DJ (eds) Progress in phycological research, vol. 8. Biopress, Bristol, pp 1-45

Edvardsen B, Eikrem W, Green JC, Andersen RA, MoonVan Der Staay SY, Medlin LK (2000). Phylogenetic reconstructions of the Haptophyta inferred from rRNA sequences and available morphological data. Phycologia 39:19-35

Fevolden SE, Schneppenheim R (1989) Genetic homogeneity of krill (Euphausia superba Dana) in the Southern Ocean. Polar Biol 9:533-539

Gäbbler S, Hayes PK, Medlin LK (2007) Methods used to reveal genetic diversity in the colony forming prymnesiophytes Phaeocystis antarctica, $P$. globosa and $P$. pouchetii--preliminary results. Biogeochemistry (this volume) doi 10.1007/s10533-007-9084-4

Hallegraeff GM (1983) Scale-bearing and loricate nanoplankton from the East Australian Current. Bot Mar 36:493-515

Hamm C, Simson DA, Merkel R, Smetacek V (1999) Colonies of Phaeocystis globosa are protected by a thin but tough skin. Mar Ecol Prog Ser 187:101-111

Jahnke J (1989) The light and temperature dependence of growth rate and elemental composition of Phaeocystis globosa Scherffel and P. pouchetii (Har.) Lagerh. in batch cultures. Neth. J Sea Res 23:15-21

Jahnke J, Baumann MEM (1986) Die marine Planktonalge Phaeocystis globosa: eine Massenform unserer Küstengewässer. Mikrokosmos 75:357-359

Jahnke J, Baumann M (1987) Differentiation between Phaeocystis pouchetii (Har.) Lagerheim and Phaeocystis globosa Scherffel. I. Colony shapes and temperature tolerances. Hydrobiol Bull 21:141-147 
Jacobsen A (2000) New aspects of bloom dynamics of Phaeocystis pouchetii (Haptophyta) in Norwegian Waters. PhD Thesis. University of Bergen, Norway, $138 \mathrm{pp}$

Jacobsen A (2002) Morphology, relative DNA content and hypothetical life cycle of Phaeocystis pouchetii (Prymnesiophyceae); with special emphasis on the flagellated cell type. Sarsia 87:338-349

Jacobsen A, Bratbak G, Heldal M (1996) Isolation and characterization of a virus infecting Phaeocystis pouchetii (Prymnesiophyceae). J Phycol 32:923-927

Karsten G (1905) Das Phytoplankton des Antarktischen Meeres nach dem Material der Deutschen TiefseeExpedition 1898-1899. Wiss. Ergeb. Deutch. Tief. Exp. Valdivia 1898-1899 Band I. , Teil 2, 136 pp

Keller MD, Ellows WKB, Guillard RL (1989) Dimethyl sulfide production in marine phytoplankton. In: Saltzmann E, Cooper W (eds) Biogenic Sulfur in the Environment. American Chemical Society, Washington DC, pp 167-182

Kooistra WHCF, Medlin LK (1996) Evolution of the diatoms (Bacillariophyta): IV. A reconstruction of their age from small subunit rRNA coding regions and the fossil record. Mol Phyl Evol 6:391-407

Kornmann P (1955) Beobachtungen an PhaeocystisKulturen. Helgol Wiss Meeres 5:218-233

Lagerheim G (1893) Phaeocystis nov. gen. grundadt på Tetraspora poucheti Har. Bot Not 1:32-33

Lancelot C, Billen G, Sournia A, Weisse T, Colijn F, Veldhuis MJW, Davies A, Wassmann P (1987) Phaeocystis blooms and nutrient enrichment in the continental coastal zones of the North Sea. Ambio 16:38-46

Lange M (1997) Molecular genetic investigation within the genus Phaeocystis (Prymnesiophyceae). P.D. dissertation, University of Bremen, Germany, $170 \mathrm{pp}$

Lange M, Chen Y-Q, Medlin LK (2002) Molecular genetic delineation of Phaeocystis species (Prymnesiophyceae) using coding and non-coding regions of nuclear and plastid genomes. Eur J Phycol 37:77-92

Larsen J, Moestrup Ø (1989) Guide to toxic and potentially toxic marine algae. Fish Inspection Service, Minister of Fisheries, Copenhagen

Medlin LK, Lange M, Baumann MEM (1994) Genetic differentiation among three colony-forming species of Phaeocystis: further evidence for the phylogeny of the Prymnesiophyta. Phycologia 33:199-212

Marchant HJ, Davison AT, Kelly GY (1991) UV-B protecting compounds in the marine alga Phaeocystis pouchetii from Antarctica. Mar Biol Berlin 109:391-395

Marchant HJ, Scott FJ, Davidson ST (2005) Haptophytes: Order Prymnesiales. In: Scott FJ, Marchant HJ (eds) Antarctic marine protists. Australian Biological Resources Study, Canberra, pp 255-275

Moestrup $\varnothing$ (1979) Identification by electron microscopy of marine nanoplankton from New Zealand including the description of four new species. $\mathrm{N} \mathrm{Z} \mathrm{J} \mathrm{Bot}$ 17:61-95

Moestrup Ø, Larsen J (1992) Potentially toxic phytoplankton 1. Haptophyceae (Prymnesiophyceae). In: Lindley S (ed) ICES Identification leaflets for plankton, leaflet
No. 179. Natural Environmental Research Council, Plymouth, pp 1-11

Montresor M, Lovejoy C, Orsini L, Procaccini G (2003) Bipolar distribution of the cyst-forming dinoflagellate Polarella glacialis. Polar Biol 26:186-194

Olbers D, Gouretski V, Seiss G, Shröter J (1962) Hydrographic atlas of the Southern Ocean. Druckhaus Nord: Bremerhaven. 82 plates

Parke M, Green JC, Manton I (1971) Observations on the fine structure of zoids of the genus Phaeocystis (Haptophyceae). J Mar Biol Assoc UK 51:927-941

Pienaar RN (1991) Thread formation in the motile cells of Phaeocystis. Electr. Microsc Soc S Africa 21:135-137

Pienaar RN (1996) Observations on the disc bearing phase of Phaeocystis in South African Waters. In: Borg M, Semesi A, Pederson M, Bergman B (eds) Current trends in marine botanical research in the East African Region (77-98) Sida, Marine Science Program, Department Of Research Co-Operation, SAREC. ISBN > 91-630-4907-4

Pouchet G (1892) Sur une algue pélagique nouvelle. Compte Rendues séance à 16 Janvier 44:34-36

Rousseau V, Vaulot D, Casotti R, Cariou V, Lenz J, Gunkel J, Baumann M (1994) The life cycle of Phaeocystis (Prymnesiophyceae): evidence and hypotheses. J Mar Syst 5:23-39

Scherffel A (1900) Phaeocystis globosa nov. spec. nebst einigen Betrachtungen über die Phylogenie niederer, insbesondere brauner Organismsen. Wiss Meer Abt Helgo 4:1-28

Schoemann V, Becquevort S, Stefels J, Rousseau V, Lancelot C (2005) Phaeocystis blooms in the global ocean and their controlling mechanisms: a review. J Sea Res 53:43-66

Scott FJ, Marchant HJ (2005) Antarctic marine protists. Australian Biological Resources Study, Canberra

Shen P, van Rijssel M, Wang Y, Songhui L, Jufang C, Qi Y (2004) Toxic Phaeocystis globosa strain from China grow at remarkably high temperatures. In: Steidinger KA, Landsberg JH, Tomas CR, Vargo GA (eds) Harmful Algae 2002. Florida Fish and Wildlife Conservation Commission, Florida Institute of Oceanography and Intergovernmental Oceanographic Commission of UNESCO, St. Petersburg, pp 396-398

Smith WO, Codispoti LA, Nelson DM, Manley T, Buskey EJ, Niebauer HJ, Cota GF (1991) Importance of Phaeocystis blooms in the high-latitude ocean carbon cycle. Nature 352:514-516

Sournia A (1988) Phaeocystis (Prymnesiophyceae): How many species? Nova Hedwigia 47:211-217

Treshnikov AF (1964) Surface water circulation in the Antarctic Ocean. In: Russian. Sovet. Antarkticheskaia Eksped., Inform. biull., 45:5-8. Eng. transl. (1965) In: Soviet Antarctic Expedition, Information Bulletin, 5:81-83

Vaulot D, Birrien J-L, Marie D, Casotti R, Veldhuis MJW, Kraay GW, Chrétiennot-Dinet M-J (1994) Morphology, ploidy, pigment composition and genome size of cultured strains of Phaeocystis (Prymnesiophyceae). J Phycol 30:1022-1035 
Veldhuis MJW, Wassmann P (eds) (2005) Bloom dynamics and biological control of Phaeocystis: a HAB species in European coastal waters. Harmful Algae 4:805-964

Verity PG, Villareal TA, Smayda TJ (1988) Ecological investigations of blooms of colonial Phaeocystis pouchetii. II. The role of life-cycle phenomena in bloom termination. J Plankton Res 10:749-766
Whipple SJ, Patten BC, Verity PG (2005) Life cycle of the marine alga Phaeocystis: A conceptual model to summarize literature and guide research. J Mar Syst 57:83-110

Zingone A, Chrétiennot-Dinet MJ, Lange M, Medlin LK (1999) Morphological and genetic characterization of Phaeocystis cordata and P. jahnii (Prymnesiophyceae), two new species from the Mediterranean Sea. J Phycol 39:1322-1337 